\title{
Realizing the City of Surabaya as a World Maritime Fulcrum Economic Power in Indonesia
}

\author{
Ivan Yulivan \\ Universitas Pertahanan RI, Kawasan IPSC Sentul, Sukahati, Kec. Citeureup, Kabupaten Bogor, \\ Jawa Barat - Indonesia 16810 \\ E-mail of the corresponding author: ivan36yulivan@gmail.com
}

\begin{abstract}
Since the 17th century, Surabaya has been used by the Dutch as a basis for economic development, especially in the eastern part of Indonesia. Surabaya's position is strategic in building the Indonesian economy to date. The world maritime Fulcrum as the current government's vision is very important to consider Surabaya as the center of economic gravity. The qualitative method of literature study is used in this paper. The discussion covers the geographical location of Surabaya which is very strategic which is in the middle of the territory of Indonesia as an archipelagic country. Surabaya is also the area of the largest strength of the Indonesian Navy fleet. Surabaya is currently the capital city of East Java Province which nationally as the second largest contributor to state revenue, all fields have high progress including the fields of education, tourism, industry. As a conclusion and as a novelty of this paper, Surabaya as an economic gateway, especially eastern Indonesia, is very worthy of being the center of Indonesia's economic power in the vision of the World Maritime Fulcrum. As a recommendation, the government needs to immediately make integrated policies that involve related parties.
\end{abstract}

Keywords:Surabaya, Indonesian Maritime Policy, Indonesian Maritime Strategy, Sea Power, World Maritime Fulcrum

DOI: $10.7176 / \mathrm{JESD} / 12-24-01$

Publication date: December $31^{\text {st }} 2021$

\section{Introduction}

Citing a fragment of the first State Speech of the President of the Republic of Indonesia for the 2014-2019 period, Mr. Ir. H. Joko Widodo said "We have long turned our backs on the oceans, seas, straits and bays. So, starting today, we will bring back the glory of our ancestors as brave sailors. Facing storms and waves on a ship named the Republic of Indonesia" (Susmoro, 2019). This statement should be a flame that continues to encourage us to make Indonesia the World Maritime Fulcrum. Since it was first announced, the President has had the desire to make Indonesia a large, strong, prosperous maritime country, through restoring Indonesia's identity as a maritime nation, securing maritime interests and security, empowering maritime potential, to realize Indonesia's economic equality (Ministry of Communication and Information of the Republic of Indonesia, 2016). Three years later after the first speech delivered on October 30, 2014, the President then signed Presidential Regulation No. 16 of 2017 concerning Indonesian Marine Policy.

According to Presidential Decree No. 16 of 2017 concerning Indonesian Maritime Policy, the Indonesian Maritime Policy is a general guideline for marine policy and steps for its implementation through programs and activities of ministries/agencies in the marine sector which are prepared in the context of accelerating the implementation of the World Maritime Fulcrum. Through this Presidential Decree, it is hoped that the policies issued by the competent institutions at the national and regional levels will be synergistically oriented towards marine and maritime affairs, so that they are able to take advantage of Indonesia's role, potential and opportunities as a maritime country.

In the Indonesian Maritime Policy, it is stated that there are 16 real geographic and demographic challenges for Indonesia that must be managed comprehensively. These challenges start from rebuilding national identity or identity as a maritime nation and state, developing infrastructure and connectivity between regions through optimizing sea transportation and reducing development gaps, including the sustainable use of all marine resources. In addition, in the field of security and defense, Indonesia's geographical and demographic conditions in achieving maritime glory still have to face several challenges such as sovereignty issues and transnational crimes.

Surabaya is a metropolitan city and also the second largest city in Indonesia after DKI Jakarta. Surabaya, which is the capital city of East Java Province, has a geographical position on the northern coast of East Java Province with the northern and eastern boundaries being the Madura Strait. Surabaya is also dubbed the Maritime City and is the spearhead of Indonesia in achieving the World Maritime Fulcrum (Ramadhan, 2018). This nickname is certainly not something that was suddenly pinned to the city which was named the city with the cleanest air in Asia (Harto, 2021).

Indonesia itself has tens of thousands of islands, vital ports from Sabang to Merauke, including cities and regions that make the sea the main economic support in their region through various sectors. But what actually makes Surabaya, which is a Metropolitan City, be considered as the spearhead of Indonesia in achieving its vision 
as the world's maritime Fulcrum? What are various government and private institutions doing in implementing the Marine Economic Policy? This big vision is certainly not an easy thing to achieve with an area as large as Indonesia. Therefore, by looking at the scope in a city, namely Surabaya, this article will explain how the picture of Indonesia as the world's maritime Fulcrum is in accordance with the conditions in Surabaya.

\section{Research Methods}

The research method used is a qualitative research method with a literature study design. Qualitative research method is a research method that produces findings that cannot be achieved using statistical procedures or other quantitative methods, and is used to examine people's lives, history, behavior, organizational functionalization, social movements, or kinship relationships and is able to produce descriptive data in the form of speech, writing, and behavior from the people being observed (Nugrahani, 2014). Through this qualitative research, it is possible to gain an understanding of reality through inductive thinking processes. Data collection techniques were carried out in a combined manner, with qualitative inductive data analysis, and the results of qualitative research emphasized meaning rather than generalizations.

Meanwhile, the design of the literature study is to deepen the data based on theoretical studies and other references related to values, culture, and norms that develop in the social situation under study. This qualitative research is descriptive in nature which aims to explain, summarize various conditions, various situations, or various variables that arise in society, which are the object of research based on what happened (Prakoso, 2021).

In this study the author will use the concept of sea power and its implications for the economy. There is also a little discussion about the implementation of public policies in explaining the integration between the competent institutions and the policies that have been issued and are based on marine affairs.

\section{Results and Discussion}

\subsection{Geographical Position of the City of Surabaya}

The city of Surabaya has an area of 52,087 hectares, with a land area of 33,048 hectares or $63.45 \%$ and a sea area managed by the City Government of 19,039 hectares or 36.55\% (Surabaya City Investment and One Stop Integrated Services Office, 2017) . Topographically, the city of Surabaya 80\% of its area is lowland with a height of 3-6 meters above sea level, except in the southern part there are two gentle hills in the Lidah area (Lakarsantri District) and Gayungan with a hang tun with an altitude of 25-50 meters above sea level. sea water (Surabaya City Investment and One-Stop Integrated Service Office, 2017). Surabaya is also dubbed as the City of Trade Services because it is the main door to the economy in the Eastern region.

One of the most important ports in Indonesia is Tanjung Perak Port, Surabaya. To enter the Port of Tanjung Perak, one way to enter is through the Surabaya West Shipping Line. The condition of the West Surabaya Shipping Channel has a maximum capacity of ship movements each year as many as 27 thousand ship movements, but in fact in 2013 there were 43 thousand movements (Komshin, 2017).

The city of Surabaya is also located downstream of the Brantas River Basin which empties into the Madura Strait. Several large rivers that function to carry and channel floods originating from upstream flow across the city of Surabaya, including the Surabaya River with an average $=26.70 \mathrm{~m} 3 /$ second, Mas River with an average $\mathrm{Q}=$ $6.26 \mathrm{~m} 3 /$ second and Jagir River with an average $\mathrm{Q}=7.06 \mathrm{~m} 3 /$ second (Surabaya City Investment and One Stop Integrated Service Office, 2017). As a downstream area, the city of Surabaya is naturally an area that overflows with water discharge from passing rivers and causes flooding in the rainy season.

\subsection{Support for Port Facilities and Connectivity}

National history, experience in maritime strategy, will assist a country in identifying national interests and priorities to be achieved as politics continues to develop in international relations (Hattendorf, 2013). Indonesia has issued Presidential Regulation Number 16 of 2017 concerning Marine Policy which consists of the National Document on Indonesian Marine Policy and the Action Plan for Indonesian Marine Policy. This later became Indonesia's maritime strategy.

In Indonesia's maritime policy, it is stated that there are challenges in developing port logistics services, shipbuilding, and marine tourism. Indonesia's maritime economy is not only based on the wealth of living and non-living natural resources, but also develops logistics services for commercial ships, pioneer ships and cruise ships, marine tourism, as well as modern and traditional shipyards that reflect maritime traditions, navigation experts, sailors., and crew. For example, utilizing international shipping traffic in the Malacca Strait, Singapore Strait, Philips Strait, and the East Coast of Sumatra requires an international standard seaport and is able to become an important international navigation traffic hub. The development of the service sector requires its own efforts, both in terms of technology, human resource capacity and access to funding. The sea must be used comprehensively while still taking into account the principles of environmental protection.

Surabaya has Tanjung Perak Port and is one of the most modern ports in Indonesia. In addition, the Surabaya City Government is also synergizing with Pelindo III to improve the quality of service to service users and the port 
environment. The addition of these facilities includes the addition of cranes, the expansion of the Container Yard, the construction of two modern warehouse units equipped with a Storage Management System, the construction of gate in/out at the Jamrud Utara and Jamrud Selatan Terminals, as well as the addition of a container consolidation area in Kalimas Baru (City Government). Surabaya, 2016). The addition of facilities and the expansion of the container area will be able to increase the flow of domestic and international containers.

As a port which is the gateway to eastern Indonesia, Tanjung Perak offers passenger ship routes to all major ports in Indonesia. Gapura Surya Nusantara Terminal which is a passenger port to connect Surabaya with ports in other cities throughout Indonesia. There is also a Cruise Ship Pier which is the main dock for cruise ships from within the country and from abroad.

The increasing number of transactions has encouraged the Tanjung Perak port to develop the Teluk Lamong terminal.

Teluk Lamong Terminal is a multipurpose terminal and includes the most sophisticated terminal in Indonesia using a semi-automatic system. With an area of 400 hectares, Teluk Lamong is the first environmentally friendly port (Green Port) in Indonesia by maximizing the use of electrically powered equipment so as to reduce fuel consumption (Surabaya City Government, 2016). Meanwhile, in the northern area of Surabaya there are also industrial and warehouse areas for Tambak Langon, Kalianak, and Margomulyo. The location of the industrial area is considered very strategic considering that it is close to the Tanjung Perak Port, Toll Road, and Wholesale Center.

Early in June 2021, the operation of the rail logistics transportation service that connects the Surabaya Container Terminal (TPS) with Kalimas Station will begin. This was done after the signing of a Memorandum of Understanding (MoU) between 4 companies namely TPS, BMC Logistics, PT Krakatau Jasa Logistik (KJL) and PT Krakatau Bandar Samudera (KBS), on April 29, 2021, right at the moment of the anniversary. TPS. In the $\mathrm{MoU}$, it was agreed to cooperate in container transportation activities from and to the Surabaya Container Terminal with the Rail transportation mode (Pelindo III, 2021).

It doesn't stop there. Precisely in 2019, the World Maritime Fulcrum Tower was built in Tanjung Perak. Pelindo III stated that the construction of the 23-floor office tower will serve as an icon for the maritime Fulcrum business center not only in Surabaya, but also in Indonesia. The plan is that floors 16 to 23 will be used for the Pelindo III business group, and floors 16 and below will be leased, for example to banking companies and shipping sector companies. Efficiency and productivity are not only realized in the operational field, but also in the administration or back office. With an investment value of more than Rp 400 billion, Tower Poros Maritim will make coordination between stakeholders at the port centralized so that it is more efficient, for all, from regulators, operators, to service users. There is even a one-stop port service center for service users, including the integration of customs services.

\subsection{Marine Tourism}

Another marine economic potential is present in the tourism sector. Although it does not have amazing natural scenery, the City of Surabaya has developed other models, for example marine tourism, development of tourist villages, and efforts to create green open spaces through garden rejuvenation. The marine economy through marine tourism, among others, is located in North Surabaya consisting of Kenjeran Beach including the Smoked Fish Center in it and has been integrated with the Suroboyo Bridge, Surabaya North Quay which is a pier with a sunset view overlooking the ocean and Suramadu Bridge, and the latest is Sontoh Marine Tourism. The sea which is a water sports tourism and clean mangrove forest.

Central Surabaya which is the center of the city and business which is synonymous with tall buildings is also one of the marine tourism in Surabaya. The first is the Kalimas river boat tour, and the second is the KRI Pasopati 401 Submarine Monument. On the east side of the Surabaya coast, the Wonorejo Mangrove Area is not only a conservation zone but also educational tourism (Surabaya City Government, 2016). The Surabaya City Government has also just opened the Bulak Fish Center which is a center for selling ornamental fish and also the Romokalisari Fish Center.

\subsection{City of Naval Base}

The potential of Surabaya City to become a miniature of "Indonesia as the World Maritime Fulcrum" can also be seen from Surabaya's position in the Central Command area. The northern coast of Surabaya is the Command of the Fleet II (Koarmada-II) of the Indonesian Navy. The Navy itself is the backbone of Indonesia's maritime power in maintaining maritime security stability both in the regional and international scope. Fleet II (formerly known as Armada Timur) is the largest naval fleet base in Indonesia, with various types of ships that are part of the fleet, maintenance and repair facilities and infrastructure, as well as logistical support and experienced human resources (Widjaja, 2021).

Surabaya is also the home of PT. PAL Indonesia (Persero) which is also located in the Naval Base Area. PT PAL Indonesia (Persero) is the largest shipbuilding company in Indonesia which has business advantages in the 
capability of the construction and design of warships and commercial ships; Submarine Construction and Maintenance, Repair, and Overhaul (MRO); Maintenance, Repair, and Overhaul of Warships, Commercial Ships, and maritime products; General Engineering for Energy and Electrification products; and Technology Development (PT PAL, 2020).

In Surabaya there is also a Class II Tanjung Perak Marine and Coastal Guard Base (PLP), which is a Technical Implementation Unit within the Directorate General of Sea Transportation which is under and responsible to the Director General of Sea Transportation as stated in the Decree of the Minister of Transportation No. KM 65 of 2002 concerning the Organization and Work Procedure of Marine and Coast Guard Bases (Ministry of Transportation of the Republic of Indonesia, 2021).

Based on the Decree of the Minister of Transportation Number KM 65 of 2002, on February 26, 2021 the Tanjung Perak Class II PLP Base for 33 years has carried out the duties of guarding, saving, securing and controlling as well as enforcing regulations in the shipping sector in marine and coastal waters.

Surabaya, as the spearhead of Indonesia's maritime Fulcrum, felt even stronger when the first tallest statue monument owned by Indonesia was successfully built. The monument is the Jalesveva Jayamahe monument which has a height of 30.6 meters made by I Nyoman Nuarta from Bali. The monument, which is located in the Indonesian Navy II Fleet Command area, was built as a symbol of the glory of the Indonesian sea. Jalesvea Jayamahe itself means "In fact, in the sea we are victorious" so that it confirms Surabaya as the "ruler" of the archipelago's oceans.

Statues can be associated as symbols. Culture in this case is defined as a symbolic carrier of a meaning, including beliefs, ritual practices, art forms, and traditional ceremonies including informal culture such as language, gossip, stories, and daily rituals (Erpul, 2014). Policy makers then make these symbols and myths into policy making, which then gives birth to a discourse produced by the political elite (Erpul, 2014). Here Surabaya is used as a symbol as a maritime city so that it influences the policies issued based on marine factors.

The Surabaya City Government represented by the Department of Food Security and Agriculture, Fisheries and Marine Affairs along with the Air and Water Police (Polairud) also routinely conducts surveillance and monitoring patrols in the East Coast area of Surabaya (Pamurbaya). This activity becomes a routine agenda once a month, as a form of reclamation supervision and monitoring of fishermen. This patrol activity as a form of reclamation supervision also monitors fishermen who violate fishing regulations. Such violations are like using tools that are not environmentally friendly in catching fish (Surabaya City Government Public Relations, 2019).

Pamurbaya is an area that has marine (ocean), estuarine (brackish water) and palustrine (fresh water) ecosystems. The types of ecosystems found in Pamurbaya include areas of mangroves, fish ponds, swamps, river estuaries and coastal areas. On the east coast of Surabaya, there is Wonorejo Mangrove Ecotourism located on an area of 871 hectares, located east of the city of Surabaya, precisely in the village of Wonorejo. This area is located on the river Jagir which empties directly into the Madura Strait. Due to its location directly adjacent to the high seas, Pamurbaya is categorized as a very critical area for erosion (Nugroho, 2021).

In addition, based on Perwali Surabaya Number 41 of 2018 concerning Amendments to Perwali Surabaya Number 56 of 2016 concerning the position, organizational structure, job descriptions and functions as well as work procedures for the food security and agriculture office of the city of Surabaya, mentioning one of the fields within the Department of Food Security and Agriculture in the city of Surabaya is in the field of fisheries and marine affairs. In carrying out its duties, the Fisheries and Marine Affairs Division is divided into 3 sections as follows: Capture Fisheries Section, Aquaculture Section, and Coastal Area Management Section (Surabaya City Food and Agriculture Security Service, 2021). The following are services provided in the Fisheries and Marine Sector, namely Application of Permits for Use of Ornamental Fish Center Stands, Training and Procurement of Facilities for Fishermen, Training and Procurement of Aquaculture Facilities, and Patrol, Assistance, and Training in Coastal Areas (City Food and Agriculture Security Service). Surabaya, 2021).

Based on the explanation above, we understand more about the important role of sea power. Sea power itself has the following urgency: (1) The control of international trade and commerce; Navy forces here play an important role in controlling and securing international trade routes which are an important element of a country's economy. (2) The usage and control of ocean resources; Naval power plays a very important role in controlling the exploration of natural resources contained in the sea. (3) The operations of navies in war; The capability of a country's navy plays a very important role in naval warfare operations, including sea control, sea denial, and power projection. And finally (4) The use of navigation and maritime economic power as instruments of diplomacy, deterrence, and political influence in time of peace. The strength of the navy and also the strength of the maritime economy is an important instrument for a country in conducting diplomacy, deterrence effect (deterrence), and provides an important influence in politics both at the national, regional and global levels, especially during peacetime (Hattendorf, 2013).

\subsection{Various Maritime Education Options}

After discussing Surabaya in responding to the challenges of the marine economy through logistics services, port and shipbuilding infrastructure and marine tourism, we turn to Surabaya in responding to challenges regarding 
maritime education. Mainly in Surabaya, there is a Marine Education and Training Doctrine Development Command. Naval Academy in charge of carrying out the first education of academies-level naval volunteer officers (Diploma IV) with study programs in Marine Defense Management, Land Aspect Marine Defense Management, Warship Mechanical Engineering, Warship Electronics Engineering, and Dimensional Logistics and Financial Management Marines (Navy Academy, 2021).

Surabaya also has various maritime education-based schools, especially in the shipping world. The first is PPNS or the Surabaya State Shipping Polytechnic. PPNS itself has 3 majors, namely Ship Building Engineering, Ship Mechanical Engineering, and Ship Electrical Engineering (Surabaya Shipping Polytechnic, 2021). In addition, the Surabaya 10 November Institute of Technology (ITS) also has a Faculty of Marine Technology which consists of 4 departments, namely the Department of Marine Engineering, the Department of Marine Systems Engineering, the Department of Marine Engineering, and the Department of Marine Transportation Engineering (Institut Teknologi 10 November Surabaya, 2021).

In Surabaya there is also the Hang Tuah Foundation which is a Navy-owned Foundation. This foundation has a vision to improve the welfare of the Navy's extended family by implementing or through quality and independent pre-school, elementary and secondary education. The Hang Tuah Foundation in Surabaya consists of the lowest to the highest levels, namely Kindergarten, Elementary School, Junior High School, Senior High School, Kal Vocational School to University.

At Hang Tuah University itself there is a Faculty of Engineering and Marine Science with majors related to fisheries and marine sciences and shipping. Meanwhile, SMK Kal in Surabaya itself is divided into 2, namely SMK Kal 1 and SMK Kal 2. SMK Kal 1 focuses more on building supply chain science competencies, while SMK Kal 2 focuses on shipping competence (Hang Tuah Foundation Surabaya, 2021). The various educational institutions above have also collaborated with agencies such as TNI and POLRI Headquarters, including various agencies in the marine economy such as shipping, logistics, and port services, including universities abroad.

Then in the field of fisheries, Universitas Airlangga has a Faculty of Fisheries and Marine Affairs which has an Aquaculture department and a Marine Department (Airlangga University Surabaya, 2021). For the shipping sector, the city of Surabaya has the Surabaya Shipping Polytechnic

The variety of choices and availability of maritime education in Surabaya aims to prepare reliable human resources in maritime affairs. This certainly answers the challenge of the availability of education in the maritime field in Surabaya for the mastery and utilization of marine science and technology, and the achievement of human resources who are experts in the maritime field. This is very important because for the sake of achieving insight into maritime identity and culture.

According to Lukman Yudho Prakoso, policy implementation can be achieved properly if it meets the factors of (1) integrative, (2) interactive, (3) transparency, (4) controlling, (5) and accountability (Prakoso, 2021). Public policies that have been decided by the authorities or the Government must be well integrated so that the complex problems and challenges faced can be solved comprehensively. Institutional, participatory integration, including technology, is very much needed in this era of disruption.

Then the policy also needs to be interactive by listening to input from experts from academics, practitioners, and related institutions so that the concept of policy and realization in the field can be appropriate and in the course of its implementation coordination between the authorized departments can run well.

Policies also really need transparency and controlling because social control is needed from the public so that policy implementation can run well. Constructive criticism and suggestions from various parties are needed so that the government feels supervised so that policies can achieve their goals and avoid deviations. Social control cannot be done without transparency, therefore the implementation of e-government is one way to increase the transparency of public policies. In addition, with the existence of e-government, accountability which is the obligation of the organization to present, report, disclose, account for all activities and activities can also be carried out because everything has been accommodated in one system.

In essence, Indonesia's maritime strategy through the Indonesian Maritime Policy which was ratified through Presidential Regulation No. 16 of 2017 concerning Indonesian Maritime Policy serves as a guide for all elements to take policies regarding marine affairs based on six principles, namely (1) insight into the archipelago, (2) sustainable development, (3) blue economy, (4) integrated and transparent management, (5) participation, and (6) equality and equity. In its implementation, the city of Surabaya still needs a lot of improvement, starting from the problem of marine damage by industrial waste, strengthening and monitoring of mangrove forests, welfare of coastal communities, improving the management and utilization of all marine resources, and building a more massive maritime culture of the Surabaya people, but through this article it can be illustrated that Surabaya has a very high chance of continuing to succeed Indonesia as the World Maritime Fulcrum.

Surabaya has the opportunity to be an example for other cities that by being guided by Indonesia's maritime strategy, geographical position, collaboration and integration of various authorized institutions, as well as technological development and scientific development in the maritime sector, can improve the economy of a region and maximize opportunities for control over the sea. . This is in line with one of the missions of the City of 
Surabaya, namely realizing an inclusive economy to improve people's welfare and opening up new jobs through strengthening local economic independence, conducive investment climate, strengthening the competitiveness of Surabaya as a center for inter-island trade and services and internationally (Surabaya City Government, 2021)

And most importantly, the economy and defense are two sides of the same coin that cannot be separated. Sea control can run optimally when Surabaya is considered safe. And we cannot separate how the role of Surabaya is to become the command center, especially Koarmada II which helps achieve Surabaya as a Maritime City.

\section{Conclusion}

Presidential Regulation Number 16 of 2017 concerning Indonesian Maritime Policy is a guideline for all elements to take policies regarding marine affairs, including for the City of Surabaya. Surabaya with its geographical condition which is directly adjacent to the Madura Strait and surrounded by rivers, then tries to maximize these opportunities to move the wheels of its economy. Surabaya and the sea are two things that cannot be separated. Supported by the Surabaya City Government Policy, Security and Pertahabab, Stakeholders, as well as the participation of the Surabaya community in the fields of economy, education, tourism, and socio-culture which refers to the marine sector, the City of Surabaya deserves and has the opportunity to become a miniature of Indonesia as the World Maritime Fulcrum..

The advice and input that I can give from this research is the importance of continuing to increase the utilization of marine resources that still need to be explored, such as in the field of fisheries and food processing, marine tourism with adequate facilities, processing industrial waste so as not to pollute the Surabaya sea, construction of river transportation, and other marine economic activities by prioritizing sustainable development or the blue economy concept. This is still a big homework for the City of Surabaya, so that the natural exploration carried out is also in line with environmentally friendly and long-term management.

\section{References}

Akademi Angkatan Laut. (2021). Tugas Pokok. Retrieved from AAL.ac.id: https://www.aal.ac.id/tupok/

Dinas Ketahanan Pangan dan Pertanian Kota Surabaya. (2021). Asal Mula Bidang Perikanan dan Kelautan. Retrieved from DKPP Surabaya: https://kpp.surabaya.go.id/bidang/perikanan

Dinas Penanaman Modal dan Layanan Terpadu Satu Pintu Kota Surabaya. (2017). Geografis. Retrieved from DPM \& PTSP: http://dpm-ptsp.surabaya.go.id/v3/pages/geografis

Erpul, O. (2014). Strategic Culture and Turkey. Journal of the Foreign Policy Institute.

Harto, A. (2021). Udara Surabaya Diklaim Terbersih di Asia Tenggara. Retrieved from Kompas: https:/www.kompas.id/baca/nusantara/2021/10/22/udara-surabaya-diklaim-terbersih-di-asia-tenggara

Hattendorf, J. (2013). What is Maritime Strategy? Soundings Sea Power Center Australia .

Humas Pemerintah Kota Surabaya. (2019). Pemkot Bersama Polairud Rutin Patroli di Kawasan Pamurbaya. Retrieved from Bangga Surabaya: https://humas.surabaya.go.id/2019/07/18/pemkot-bersama-polairud-rutinpatroli-di-kawasan-pamurbaya/

Humas Pemkot Surabaya. (2018). Twitter Bangga Surabaya. Retrieved from https://twitter.com/banggasurabaya/status/969747939227652096

Institut Teknologi 10 November Surabaya. (2021). Fakultas Teknik Kelautan. Retrieved from https://www.its.ac.id/id/kuliah-di-its/fakultas-dan-departemen/fakultas-teknologi-kelautan/

Kementerian Komunikasi dan Informatika Republik Indonesia. (2016). Menuju Poros Maritim Dunia. Retrieved from Kominfo.go.id: https://www.kominfo.go.id/content/detail/8231/menuju-poros-maritimdunia/0/kerja_nyata

Kementerian Perhubungan Republik Indonesia. (2021). Pangkalan PLP Kelas II Tanjung Perak Komit Jaga Keselamatan dan Keamanan Pelayaran di Perairan Indonesia. Retrieved from https://hubla.dephub.go.id/home/post/read/9202/pangkalan-plp-kelas-ii-tanjung-perak-komit-jagakeselamatan-dan-keamanan-pelayaran-di-perairan-indonesia

Komshin, A. M. (2017). Pemodelan Sebaran Tumpahan Minyak di Alur Pelayaran Barat Surabaya. Departemen Teknik Geomatika FTSLK ITS Geoid Vol 12, No.2, 190-194.

Nasution, A. (2019). SMK Kal-1 Cetak Lulusan Cinta Laut Lewat Wisata Bahari. Retrieved from Suara Karya: https://m.suarakarya.id/detail/89986/SMK-KAL-1-Cetak-Lulusan-Cinta-Laut-Lewat-Wisata-Bahari

Nugrahani, F. (2014). Metode Penelitian Kualitatif dalam Penelitian Pendidikan Bahasa. Solo: Cakra Books.

Nugroho, S. (2021). Desain Konseptual dan Pola Operasi Perahu Wisata di Daerah Pantai Timur Surabaya (Pamurbaya). Teknik Perkapalan Fakultas Teknologi Kelautan ITS Surabaya.

Pelindo III. (2021). Angkutan Logistik Kereta Api Resmi Beroperasi di Terminal Petikemas Surabaya. Retrieved from Majalah Dermaga: https://www.majalahdermaga.co.id/emagz/files/Edisi $263 \mathrm{JuLi}$ 2021.pdf

Pemerintah Kota Surabaya. (2016). Surabaya City Profile 2016. Retrieved from Surabaya.go.id: https://www.surabaya.go.id/uploads/attachments/2016/10/13986/profil_surabaya_2016_vfinal_ar_compress ed_compress.pdf 
Pemerintah Kota Surabaya. (2021). Visi Misi Kota Surabaya. Retrieved from Surabaya.go.id: https://surabaya.go.id/id/berita/60539/visi-misi-kota-surabaya

Politeknik Perkapalan Surabaya. (2021). Jurusan dan Program Studi. Retrieved from PPNS Surabaya: https://ppns.ac.id/jurusan-dan-program-studi-ppns/

Prakoso, K. P. (2021). Urgensi Transformasi Networking dan Driver Force Kebijakan Pertahanan. Garut: CV Aksara Global Akademia.

Pratomo, I. (2017). Inspirasi Surabaya Menjadi Kebanggaan Bangsa. Retrieved from Kompasiana: https://www.kompasiana.com/prattemm/59528b52a7249b64a6768792/inspirasi-surabaya-menjadikebanggaan-bangsa?page $=4 \&$ page images $=1 \#$ google vignette

PT PAL. (2020). Profil Perusahaan. Retrieved from https://pal.co.id/dewan-direksi-3/

Ramadhan, B. (2018). Surabaya, Kota Ujung Tombak Poros Maritim Indonesia. Retrieved from Good News From Indonesia: $\quad$ https://www.goodnewsfromindonesia.id/2018/05/31/surabaya-kota-ujung-tombak-porosmaritim-indonesia

Sari, S. M. (2019). Pemerintah: Teluk Lamong jadi Contoh Pelabuhan Hijau. Retrieved from Ekonomi.Bisnis.com: https://ekonomi.bisnis.com/read/20190903/98/1143876/pemerintah-teluk-lamong-jadi-contoh-pelabuhanhijau

Susmoro, H. (2019). The Spearhead of Sea Power. Bantul: Pandiva Buku.

Universitas Airlangga Surabaya. (2021). Fakultas Perikanan dan Kelautan. Retrieved from https://fpk.unair.ac.id/dosen-kelautan/

Widjaja, S. (2021). Mengangkat Kembali Kota Surabaya sebagai Kota Maritim Guna Mendukung Indonesia Poros Maritim Dunia. (F. Kodiklatal, Interviewer)

Yayasan Hang Tuah Surabaya. (2021). SMK KAL Surabaya. Retrieved from https://www.hangtuahsurabaya.or.id/read/16/smk-kal 